\title{
Experimental studies on predation and cannibalism of the settlers of Chasmagnathus granulata and Cyrtograpsus angulatus (Brachyura: Grapsidae)
}

\author{
Tomás A. Luppi ${ }^{\text {a, }}$, Eduardo D. Spivak ${ }^{a}$, Klaus Anger ${ }^{b}$ \\ a Dto. de Biología, FCEyN, UNMDP, c.c. 1245, 7600 Mar del Plata, Argentina \\ ${ }^{\mathrm{b}}$ Biologische Anstalt Helgoland, AWI, 27483 Helgoland, Germany
}

Received 15 March 2000; received in revised form 29 May 2001; accepted 4 July 2001

\begin{abstract}
The grapsid crabs Chasmagnathus granulata and Cyrtograpsus angulatus are considered as key species within the benthic communities of estuaries and brackish coastal lagoons in the southwestern Atlantic region. In controlled laboratory experiments, we studied the intensity of interspecific predation as well as intra- and intercohort cannibalism in setllers in relation to refuge availability, predator characteristics (species, size, sex, nutritional state), and the presence or absence of an alternative food source (Artemia nauplii). In both species, the intensity of intracohort cannibalism among recently settled crabs (instars I and II, "settlers") was low, with ca. 5\% mortality during $48 \mathrm{~h}$ experimental observation periods. Larger juveniles and adults of both species, by contrast, preyed heavily on the settlers. Predation was significantly reduced when refuges were available for the settlers. Hunger of the predators enhanced in general the predation rate. In the presence of alternative food, the consumption of settlers was significantly reduced. In C. granulata, adult females ate more settlers than the males, probably as a consequence of differences in the morphometric traits of their chelae. Cannibalism and predation by juvenile and adult crabs may play an important role in the regulation of recruitment success for both species and hence, in the structure of estuarine benthic communities. (C) 2001 Elsevier Science B.V. All rights reserved.
\end{abstract}

Keywords: Argentina; Cannibalism; Coastal lagoon; Predation; Refuge; Settler

\section{Introduction}

Recruitment patterns in marine benthic species with pelagic larvae are the result of both pre- and post-settlement processes (Luckenbach, 1984; Connell, 1985; Gaines and

\footnotetext{
* Corresponding author. Fax: +54-23-753-150.

E-mail address: taluppi@uni.mdp.edu (T.A. Luppi).
} 
Roughgarden, 1985; Bertness et al., 1992; Eggleston and Armstrong, 1995). Among post-settlement processes, predation is a key factor explaining settler or early juvenile mortality (Thorson, 1966; Keough and Downes, 1982; Gosselin and Qian, 1997).

Intraspecific predation, i.e. cannibalism, may participate in the regulation and structuring of animal populations (Fox, 1975; Polis, 1981, 1988). This has been observed in the field in several marine and estuarine crab species such as Callinectes sapidus (Hines et al., 1987; Ruiz et al., 1993; Hines and Ruiz, 1995; Smith, 1995), Cancer magister (Fernández et al., 1993a; Botsford and Hobbs, 1995; Eggleston and Armstrong, 1995), Hemigrapsus penicillatus (Kurihara and Okamoto, 1987), Chionoecetes opilio (Lovrich and Sainte-Marie, 1997) and Carcinus maenas (Moksnes, 1999). Cannibalism is the main cause of juvenile mortality in size-structured populations of crabs (Botsford and Wickham, 1978; Hines et al., 1990), and affects population dynamics by modifying the distribution of individuals, recruitment patterns, and/or population size (Lovrich and Sainte-Marie, 1997).

The intensity of cannibalism in decapod crustaceans can be affected by refuge availability (Heck and Wilson, 1987; Kurihara et al., 1988; Navarrete and Castilla, 1990; Wilson et al., 1990; Olmi and Lipcius, 1991; Heck and Hambrook, 1991; Fernández et al., 1993b; Moksnes et al., 1997), predator size (Kurihara and Okamoto, 1987; Lovrich and Sainte-Marie, 1997; Fernández, 1999; Kneib et al., 1999) and sex (Cerdá and Wolff, 1993), predator assemblages (Moksnes et al., 1997), prey size (Dutil et al., 1997; Fernández, 1999), hunger of the predator (Okamoto and Kurihara, 1989), the availability of alternative food (Kurihara and Okamoto, 1987; Dutil et al., 1997), or the molt stage of prey (Dutil et al., 1997; Moksnes et al., 1997; Visser, 1997).

Salt marshes in Mar Chiquita coastal lagoon (Argentina) are inhabited by the grapsid crabs Cyrtograpsus angulatus (Dana, 1851) and Chasmagnathus granulata (Dana, 1851) (Olivier et al., 1972a; Spivak et al., 1994). Adult C. angulatus live in tidal mud flats, whereas juveniles and settlers are found in crevices within polychaete (Ficopomatus enigmaticus) "reefs" and under stones or bivalve shells (Spivak et al., 1994; Gutierrez and Iribarne, 1999). In biogenic substrates such us polychaete reefs, settlers may be eaten mainly by conspecific juveniles, but also by adult crabs ( $C$. altimanus) or gobiid fishes (Gobiosoma parri) (Obenat and Pezzani, 1989; Lucifora, personal communication). C. granulata dig and inhabit semi-permanent burrows in mudflats and Spartina densiflora grasslands (Boschi, 1964; Spivak et al., 1994; Iribarne et al., 1997). Juveniles live near the conspecific adults in separate burrows, but usually juvenile and adult burrows are interconnected. Settlers are found within the adult burrows (Spivak et al., 1994; Luppi, 1999) or in siphonal holes of clams (Tagelus plebeius) (Gutierrez and Iribarne, 1998). Only occasionally settlers of $C$. granulata appeared in the microhabitat of C. angulatus, and viceversa (Luppi, 1999).

Studies of stomach contents of adult $C$. angulatus and C. granulata showed that both species are cannibalistic (Olivier et al., 1972b; D'Incao et al., 1990). Juveniles of pleuronectiform and perciform fishes and several bird species prey on megalopae and settlers of both crabs (Rivera Prisco, 1998; Valero, personal communication).

In Mar Chiquita, settlers populations of both crab species show strong density changes over short periods of time (Luppi, 1999), suggesting that recruitment success may be regulated by post-settlement processes. In this study, we investigated cannibal- 
ism and predation by juvenile and adult $C$. angulatus and $C$. granulata on settlers of both species. The goals were to evaluate the potential for intra- and inter-cohort cannibalism and interspecific predation in the two species, and the effects of refuge availability, of predator sex, size and hunger level, and of an alternative food source on settler mortality. These experimental results are discussed in relation to recruitment patterns and size distribution in the field (Luppi, 1999).

\section{Materials and methods}

\subsection{Study area}

Mar Chiquita is the southernmost coastal lagoon of the warm temperate Southwestern Atlantic $\left(37^{\circ} 32^{\prime}-37^{\circ} 45^{\prime} \mathrm{S} ; 57^{\circ} 19^{\prime}-57^{\circ} 26^{\prime} \mathrm{W}\right)$. The extent of water exchange with the adjacent ocean depends on the tidal amplitude and the direction and speed of wind (Olivier et al., 1972a; Reta et al., 1997). Temperature and salinity have daily, seasonal and geographic variations (Anger et al., 1994; Martos and Reta, 1997; Marcovecchio et al., 1997).

\subsection{Field collection}

The upper size limit of "settlers" was defined as $2.4 \mathrm{~mm}$ carapace width $(\mathrm{CW})$ in $C$. angulatus and $2.2 \mathrm{~mm}$ in $C$. granulata. These values represent the average $\mathrm{CW}$ of juvenile crabs for combined instars II and III (obtained from laboratory cultures; Luppi, 1999). Two size classes of predators were selected: (1) "juveniles" from 6 to $8 \mathrm{~mm} \mathrm{CW}$, (2) "adults" from 24 to $28 \mathrm{~mm}$ CW. These size classes are characterized in Table 1. Juveniles and settlers of $C$. angulatus were collected from $F$. enigmaticus reefs. Reef pieces were carried to the laboratory and examined for small crabs. $C$. angulatus adults were collected by hand in the intertidal. Settlers, juveniles and adults of $C$. granulata were collected within and around burrows. CW was measured to the nearest 0.1 and $0.01 \mathrm{~mm}$ with a Vernier caliper or an ocular micrometer on stereomicroscope, respectively.

Table 1

Size (range and mean \pm standard deviation, sd) of $C$. angulatus and $C$. granulata used in the experiments as prey and predators, respectively

\begin{tabular}{|c|c|c|c|c|c|}
\hline & & \multicolumn{4}{|c|}{ Carapace width $(\mathrm{mm})$} \\
\hline & & \multicolumn{2}{|c|}{ C. angulatus } & \multicolumn{2}{|c|}{ C. granulata } \\
\hline & & Range & Mean \pm sd & Range & Mean \pm sd \\
\hline Prey & settlers & $1.5-2.4$ & $1.9 \pm 0.3$ & $1.35-2.2$ & $1.8 \pm 0.2$ \\
\hline \multirow[t]{2}{*}{ Predators } & juveniles & $6-8$ & $7.2 \pm 0.6$ & $6-8$ & $7.1 \pm 0.6$ \\
\hline & adults & $24-28$ & $25.9 \pm 1.6$ & $24-28$ & $25.7 \pm 1.7$ \\
\hline
\end{tabular}




\subsection{Rearing of crabs}

Settlers and juveniles were maintained in 31 plastic flasks, adults in 201 plastic boxes filled with $23 \%$ o aerated water. This salinity was obtained by mixing $34 \%$ o coastal seawater and tap water, both filtered through a $10-\mu \mathrm{m}$ mesh. Settlers were fed with Artemia sp. nauplii once a day after each water change. Juveniles were fed with Tetra Bits $^{\mathrm{TM}}$ and adults with Truchina ${ }^{\mathrm{TM}}$ pellets. Juveniles of both species were able to catch and eat live Artemia sp. nauplii and could be reared successfully only with this food (Anger and Ismael, 1997; Luppi, 1999; Spivak, 1999). No crabs stayed in the laboratory longer than 3 days before the experiments.

\subsection{Predation experiments}

\subsubsection{General procedure}

All experiments were conducted in cylindrical PVC flasks (diameter $11.5 \mathrm{~cm}$, height $13 \mathrm{~cm}$ ) filled with $600 \mathrm{ml} 23 \%$ water. As a refuge, plastic sponges (ca. $300 \mathrm{ml}$ volume; pore diameter $4.6 \pm 0.4 \mathrm{~mm}$, fibre diameter $0.63 \pm 0.03 \mathrm{~mm}$ ) were used. Since these refuges were made of flexible material, juveniles can enter them although their $\mathrm{CW}$ exceeds the average pore diameter. Predators maintained without food for $48 \mathrm{~h}$ were considered as "starved".

A replicate consisted on one juvenile or adult (predator) and six settlers (preys) in a flask. The predator was introduced first in each flask, and the settlers were added 30 min later. This number of settlers was chosen on the basis of densities usually observed in the field (Luppi, 1999). Individuals with limb autotomies were excluded, and all were used only once. Each experiment lasted $48 \mathrm{~h}$. After this period, the predator was separated, and the number of remaining live prey was counted. If the predator died or molted during the experiment, this replicate was discarded and repeated. The proportion of settlers lost plus settlers with part of their body consumed, was named "proportional mortality" (PM) according to Moksnes et al. (1997). The intact died settlers were not included in the PM.

\subsubsection{Statistical procedures}

The experimental design comprised in all experiments two or more factors (except experiment 1). All replicates in each treatment were randomly distributed (Hurlbert, 1984). Normality or homocedasticity assumptions were not met by PM data, despite transformations, in some cases. The fixed-factor ANOVA model was applied to analyse the data in all experiments. The analysis of variance are robust to heterogeneity of variances and non-normality, particularly with large samples in each treatment (Underwood, 1997). When significant effects or interactions were detected, a multiple comparison Student-Newman-Keuls test was applied (Underwood, 1997). The results from experiments without juveniles or adults (intracohort settler cannibalism) were used as a control in each experiment. Cannibalism and predation data were compared with a $\chi^{2}$ test after Yates' correction. In all statistical tests, differences were considered significant when $p \leq 0.05$. 


\subsubsection{Experiment 1 (control for intracohort cannibalism)}

Intraspecific predation among settlers, with and without refuge, was evaluated in 20 replicates for each combination of species and refuge availability (total number of replicates: $n=80$ ). To test the null hypotesis of no differences in the mean PM, with or without refuge, a Student's $t$-test was performed for each species.

\subsubsection{Experiment 2}

The effect of predator size on the intensity of cannibalism and interspecific predation of settlers, juveniles and adults of both species, fed or starved, with or without refuge availability, were tested with 20 replicates per combination (except for fed adult $C$. angulatus in combination with settlers of $C$. granulata, with or without refuge: $n=10$ ); hence, the total number of replicates was $n=620$. Adults of both sexes were randomly assigned in order to randomize possible sex differences in predatory effects. A three-way ANOVA model (with unequal replicates for $C$. angulatus as predators and $C$. granulata as prey) was performed to test for differences in the mean PM among predator size, feeding condition, and refuge availability.

\subsubsection{Experiment 3}

Effect of predator sex on the intensity of cannibalism of starved adults, males or females of both species, against settlers, with or without a refuge was tested with 20 replicates per combination (total number of replicates, $n=160$ ). A two-way ANOVA model was performed to test for differences in the mean PM among sex of predators and refuge availability.

\subsubsection{Experiment 4}

In the field, also other food items are present, so that alternative food may affect intercohort cannibalism. Starved juveniles were used as predators, with or without availability of alternative food ( Artemia sp. nauplii), with 20 replicates per combination (total number of replicates, $n=80$ ). A two-way ANOVA model was performed to test for differences in the mean PM among alternative food and refuge availability.

\subsubsection{Experiment 5}

Settlers, juveniles, and adults of $C$. granulata live together in or around adult burrows. Consequently, an experiment was designed to evaluate the predation by juveniles alone (see Experiment 2) or by juveniles plus conspecific adults. A juvenile and an adult (male, or female), both starved, were used as predators, with 10 replicates per combination (total number of replicates, $n=60$ ). A two-way ANOVA model was performed to test for differences in the mean PM among sex and size of predators and refuge.

\subsubsection{Sex-related differences in chela size}

In order to determine sex-related differences in chela size, 30 adults of each sex and species (size: 24-28 mm CW) were collected. Their carapace width, chela length, height, width and gape (distance between tips of propodus and dactylus) were measured. 
To compare mean values between sexes, a $t$-test was performed. To meet assumption of normality and homogeneity of variance, data were $1 / x$ transformed.

\section{Results}

\subsection{Experiment 1: intracohort cannibalism}

PM was very low in experiments to test for intracohort cannibalism among conspecific settlers (control experiment). There was no significant influence of refuge availability on PM in either species ( $C$. granulata, $t=0.872, p=0.38$ and $C$. angulatus, $t=0.297, p=0.76)$ (Fig. 1).

3.2. Experiment 2: effect of predator species, predator size and predator hunger on cannibalism and predation

In the four combinations of prey and predator (Table 2), PM of settlers was significantly affected by predator size (juveniles vs. adults) and refuge availability. Predator starvation had not a statistically significant effect on intensity of cannibalism only in the treatment combining juvenile $C$. angulatus with settlers of $C$. granulata. The power of analysis is give in Table 2 .

When C. granulata was cannibal or predator all interactions were statistically significant. The interaction between predator size and refuge availability was statistically significant when prey and predator were $C$. angulatus (Table 2). Without a refuge, more settlers of $C$. granulata were killed by conspecific juveniles than by adults. Juveniles ate all settlers within the 48-h experimental periods, regardless of being starved or fed. The PM of settlers in the presence of starved adults reached 0.69 (Fig. 2A). With refuges, in

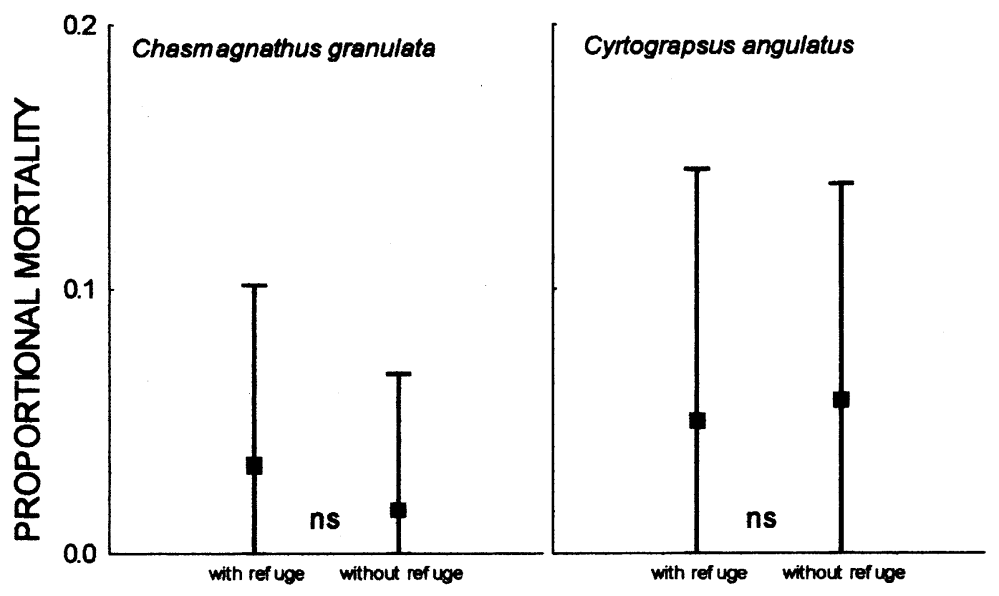

Fig. 1. Intracohort proportional mortality of settlers, with or without refuges; ns: not significant for $t$-test. 
Table 2

Results of the three-way ANOVA of experiment 2, with predator size, starvation and refuge as factors and proportional mortality of settlers as response variable

\begin{tabular}{|c|c|c|c|c|c|c|c|c|}
\hline \multirow{3}{*}{$\begin{array}{l}\text { Settler (prey) } \\
\text { Predator } \\
\text { Factors }\end{array}$} & \multirow{2}{*}{\multicolumn{4}{|c|}{$\begin{array}{l}\text { C. granulata } \\
\text { C. granulata }\end{array}$}} & \multirow{2}{*}{\multicolumn{4}{|c|}{$\begin{array}{l}\text { C. angulatus } \\
\text { C. granulata }\end{array}$}} \\
\hline & & & & & & & & \\
\hline & $F$ & $d f$ & $p$ & $P$ & $F$ & $d f$ & $p$ & $P$ \\
\hline Size (A) & 128.1 & 1 & $<0.001$ & $>0.8$ & 109.5 & 1 & $<0.001$ & $>0.8$ \\
\hline Starvation (B) & 24.8 & 1 & $<0.001$ & $<0.8$ & 11.2 & 1 & $<0.01$ & $<0.8$ \\
\hline Refuge (C) & 547.3 & 1 & $<0.001$ & $>0.8$ & 164.7 & 1 & $<0.001$ & $>0.8$ \\
\hline $\mathrm{A} \times \mathrm{B}$ & 16.6 & 1 & $<0.001$ & $<0.8$ & 11.2 & 1 & $<0.01$ & $<0.8$ \\
\hline $\mathrm{A} \times \mathrm{C}$ & 68.9 & 1 & $<0.001$ & $>0.8$ & 23.9 & 1 & $<0.001$ & $>0.8$ \\
\hline $\mathrm{B} \times \mathrm{C}$ & 12 & 1 & $<0.001$ & $<0.8$ & 7.4 & 1 & $<0.01$ & $<0.8$ \\
\hline $\mathrm{A} \times \mathrm{B} \times \mathrm{C}$ & 19.1 & 1 & $<0.001$ & $<0.8$ & 7.4 & 1 & $<0.01$ & $<0.8$ \\
\hline
\end{tabular}

Settler (prey) C. angulatus

Predator $\quad$ C. angulatus

\begin{tabular}{|c|c|c|c|c|c|c|c|c|}
\hline Factors & $F$ & $d f$ & $p$ & $P$ & $F$ & $d f$ & $p$ & $P$ \\
\hline Size (A) & 51.2 & 1 & $<0.001$ & $>0.8$ & 129.1 & 1 & $<0.001$ & $>0.8$ \\
\hline Starvation (B) & 24.2 & 1 & $<0.001$ & $>0.8$ & 0.047 & 1 & 0.82 & $<0.8$ \\
\hline Refuge (C) & 198.5 & 1 & $<0.001$ & $>0.8$ & 136.6 & 1 & $<0.001$ & $>0.8$ \\
\hline $\mathrm{A} \times \mathrm{B}$ & 3.2 & 1 & 0.075 & $<0.8$ & 0.1 & 1 & 0.74 & $<0.8$ \\
\hline $\mathrm{A} \times \mathrm{C}$ & 7.2 & 1 & $<0.01$ & $<0.8$ & 0 & 1 & 1 & $<0.8$ \\
\hline $\mathrm{B} \times \mathrm{C}$ & 0.8 & 1 & 0.37 & $<0.8$ & 1.19 & 1 & 0.27 & $<0.8$ \\
\hline $\mathrm{A} \times \mathrm{B} \times \mathrm{C}$ & 1.2 & 1 & 0.26 & $<0.8$ & 0.1 & 1 & 0.74 & $<0.8$ \\
\hline
\end{tabular}

$P$ : power of the analysis.

the presence of adults, PM of settlers declined to values not significantly different from controls while in the presence of starved juveniles PM of settlers was reduced but remained greater than controls $(\mathrm{PM}=0.15)$.

Predation by $C$. angulatus on $C$. granulata. Without a refuge, juvenile $C$. angulatus ate all settlers of $C$. granulata within $48 \mathrm{~h}(\mathrm{PM}=1)$. Adults had a strong effect only when they were starved $(\mathrm{PM}=0.62$; Fig. $2 \mathrm{~B})$. The PM decreased significantly when a refuge was available but still differed significantly from the control $(\mathrm{PM}=0.28)$ when juveniles, starved or fed, were the predators. When predator and prey were $C$. angulatus there was a high PM of settlers caused by juveniles and adults, especially when the predators were starved and without refuge (Fig. 2C). With a refuge, PM diminished, mainly when predators were adults $(\mathrm{PM}<0.1$; not significantly different from the control). Juveniles caused generally high PM ( 0.31 and 0.56 for fed and starved crabs, respectively). When $C$. granulata prey on $C$. angulatus the results were similar to the cannibalism experiments with $C$. angulatus, when effects of size and refuge are considered. However, there were no differences between the effect of fed and starved predators. Without a refuge, juveniles $C$. granulata caused a maximum PM (0.92), while PM reached only 0.51 when adults were present as predators. With a refuge, PM caused by adults was low and did not differ from the control (Fig. 2D). 

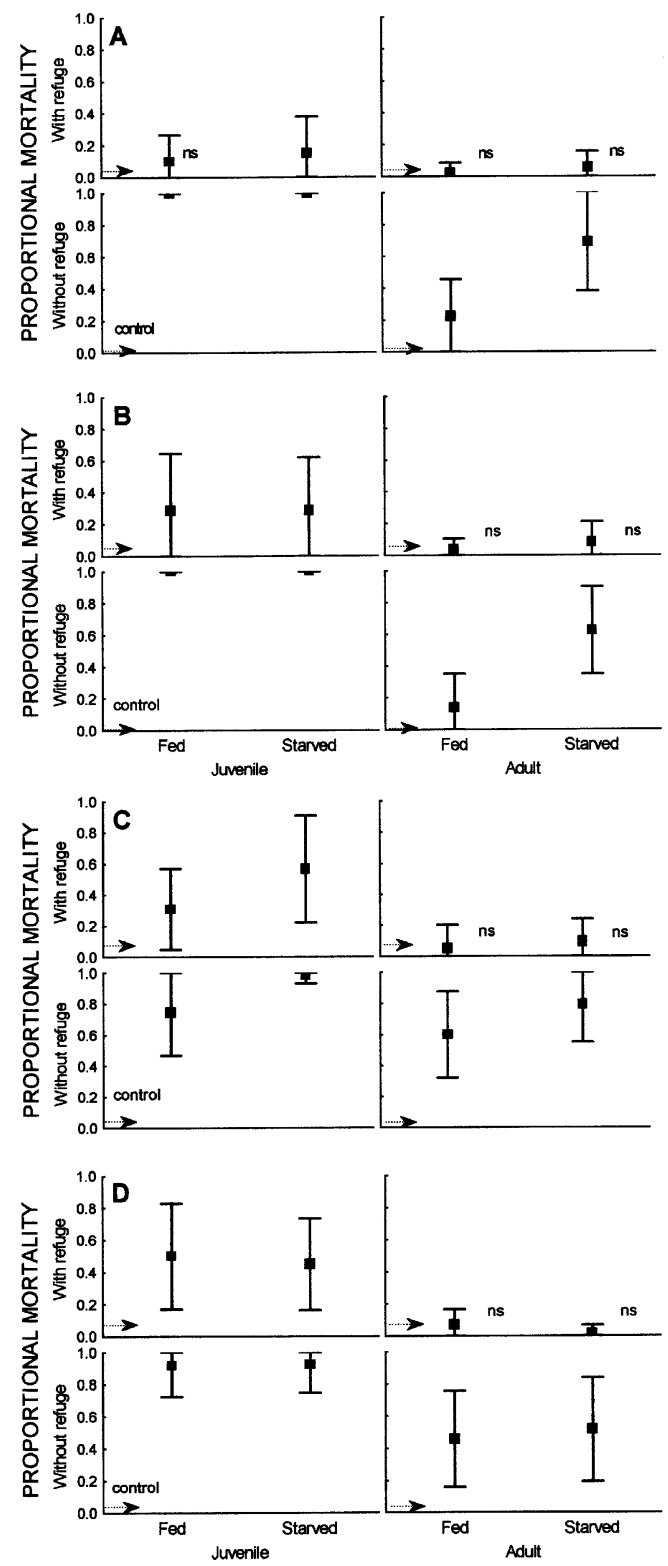

Fig. 2. Proportional mortality (mean \pm standard deviation) of settlers with juveniles and adults as predators or cannibals, fed or starved, with or without refuge. (A) settlers and predators $C$. granulata, (B) settlers $C$. granulata, predators $C$. angulatus, (C) settlers and predators $C$. angulatus, (D) settlers $C$. angulatus, predators C. granulata. Arrows: levels of proportional mortality with settlers alone (control). In each case, the results were compared with the control values ( $\chi^{2}$ test); ns: not significant differences. 
Table 3

Results of the two-way ANOVA of experiment 3, with adult sex and refuge as factors and proportional mortality of settlers as response variable

C. granulata

\begin{tabular}{lllll}
\hline Factors & $F$ & $d f$ & $p$ & $P$ \\
\hline Sex (A) & 16.8 & 1 & 0.0001 & $>0.8$ \\
Refuge (B) & 6.7 & 1 & 0.011 & $<0.8$ \\
A $\times$ B & 0.003 & 1 & 0.95 & $<0.8$
\end{tabular}

C. angulatus

\begin{tabular}{lllll}
\hline Factors & $F$ & $d f$ & $p$ & $P$ \\
\hline Sex (A) & 54.5 & 1 & $<0.0001$ & $>0.8$ \\
Refuge (B) & 0.03 & 1 & 0.84 & $<0.8$ \\
A $\times$ B & 2.9 & 1 & 0.089 & $<0.8$ \\
\hline
\end{tabular}

$P$ : power of the analysis.

\subsection{Experiment 3: effect of predator sex on cannibalism and predation}

PM was significantly affected by sex of the adult predators in $C$. granulata and by refuge in both species. There were no interactions between these variables (Table 3). The power of analysis were high for significant differences in main factors $(>0.8)$ but low for not significant differences in main factors and interactions. In C. angulatus, PM was higher than the control only when a refuge was absent $(\mathrm{PM}=0.51$ for males and $\mathrm{PM}=0.63$ for females, Fig. 3). C. granulata males caused a significantly higher PM than control only when no refuge was available $(\mathrm{PM}=0.21)$. With $C$. granulata females

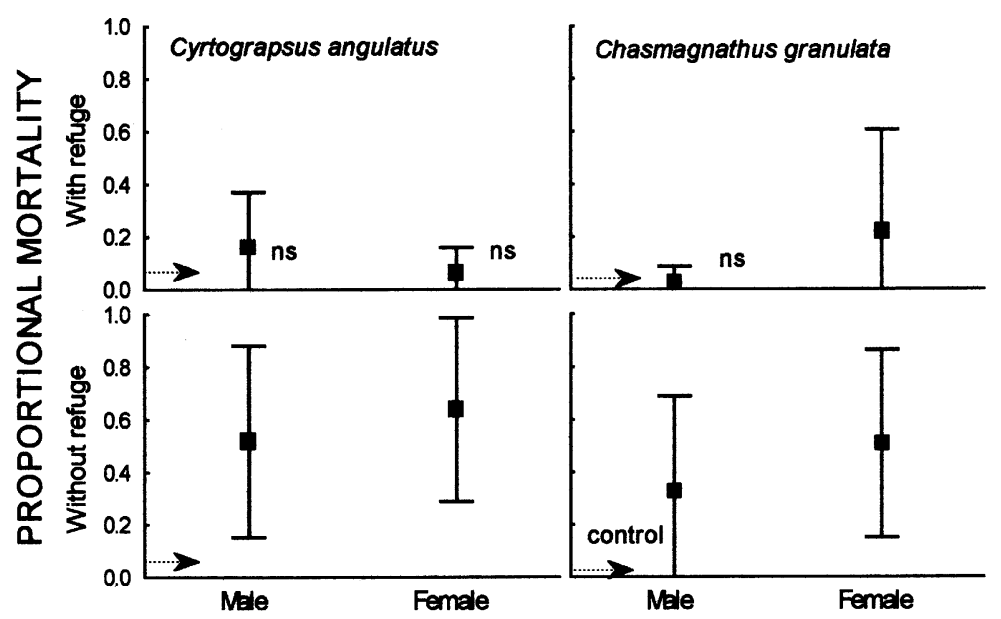

Fig. 3. Proportional mortality (mean \pm standard deviation) of C. granulata and C. angulatus settlers with starved conspecific adults, males or females, as predators, with or without refuges. For more explanations see caption of Fig. 2. 
Table 4

Results of the two-way ANOVA of experiment 4, with alternative food and refuge as factors and proportional mortality of settlers as response variable

C. granulata

\begin{tabular}{lrlll}
\hline Factors & \multicolumn{1}{c}{$F$} & $d f$ & $p$ & $P$ \\
\hline Food (A) & 48.2 & 1 & $<0.0001$ & $>0.8$ \\
Refuge (B) & 112.4 & 1 & $<0.0001$ & $>0.8$ \\
A $\times$ B & 24.6 & 1 & $<0.0001$ & $>0.8$
\end{tabular}

C. angulatus

\begin{tabular}{lllll}
\hline Factors & $F$ & $d f$ & $p$ & $P$ \\
\hline Food (A) & 52.2 & 1 & $<0.0001$ & $>0.8$ \\
Refuge (B) & 88.6 & 1 & $<0.0001$ & $>0.8$ \\
$\mathrm{~A} \times \mathrm{B}$ & 4.4 & 1 & 0.037 & $<0.8$ \\
\hline
\end{tabular}

$P$ : power of the analysis.

as predators, PM (0.32 with, and 0.51 without refuge) was significantly higher than with males $(\mathrm{PM}=0.02$ with, and $\mathrm{PM}=0.21$ without, refuge $)$.

\subsection{Experiment 4: effect of alternative food on cannibalism}

The presence of Artemia sp. nauplii and of refuges significantly reduced the PM of settlers in both species. Interactions between these two factors were statistically significant (Table 4). The power of analysis were high for main factors and interactions $(>0.8)$. PM was low and did not differ significantly from controls when refuges were available $(C$. angulatus $\mathrm{PM}=0.03$ and $C$. granulata $\mathrm{PM}=0.04)$, but high when there was no refuge $(\mathrm{PM}=0.69$ and $\mathrm{PM}=0.35$, respectively) (Fig. 4).

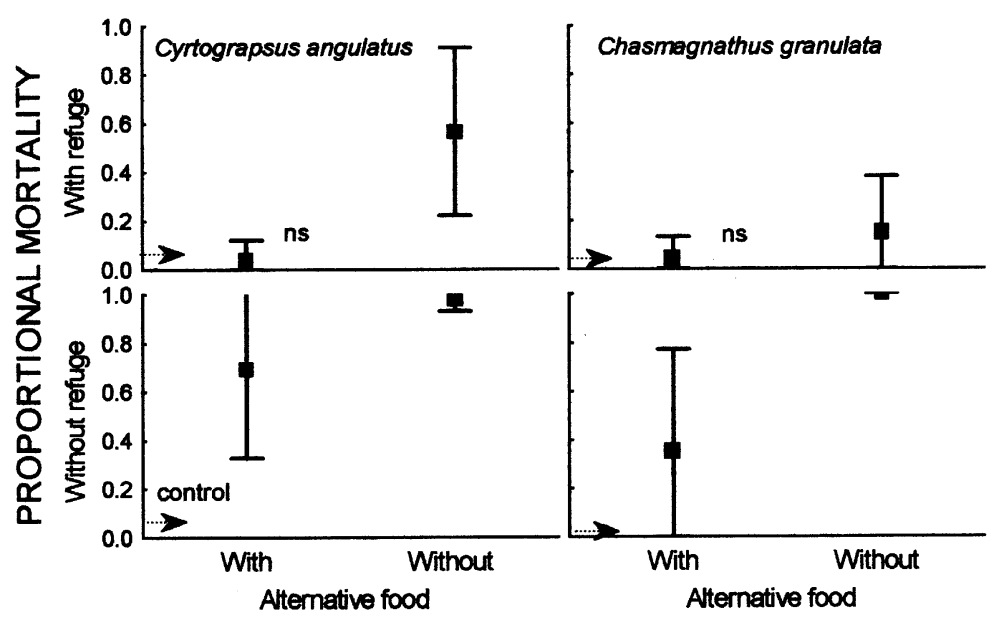

Fig. 4. Proportional mortality (mean \pm standard deviation) of $C$. granulata and C. angulatus settlers with starved conspecific juveniles as predators, with or without alternative food and refuge. For more explanations see caption of Fig. 2. 
Table 5

Results of the two-way ANOVA of experiment 5, with predator combination and refuge as factors and proportional mortality of settlers as response variable

\begin{tabular}{lrlll}
\hline Factors & \multicolumn{1}{c}{$F$} & $d f$ & $p$ & $P$ \\
\hline Sex (A) & 8.2 & 3 & $<0.0001$ & $>0.8$ \\
Refuge (B) & 71.6 & 1 & $<0.0001$ & $>0.8$ \\
$\mathrm{~A} \times \mathrm{B}$ & 5.4 & 3 & 0.0021 & $>0.8$ \\
\hline
\end{tabular}

$P$ : power of the analysis.

3.5. Experiment 5: effect of conspecific adult crabs on cannibalistic activity of juvenile C. granulata

Sex of adults and reproductive condition of adult females both influenced the level of settler PM caused by juveniles. Refuge availability and predator sex (or reproductive condition) had a significant interaction as factors (Table 5). The power of analysis were high for main factors and interaction $(>0.8)$. PM decreased when adults were placed together with juveniles, but the effect varied according to sex and reproductive conditions of the adult. Refuges always diminished the settler PM; when adult males were present, PM did not differ significantly from control. Without refuges, settler PM increased more with females and juveniles than with males, as predators. The differences were significant. When juveniles were placed together with an ovigerous female, settler PM was significantly lower than with juveniles alone; however non-ovigerous female had no significant effect (Table 5, Fig. 5).

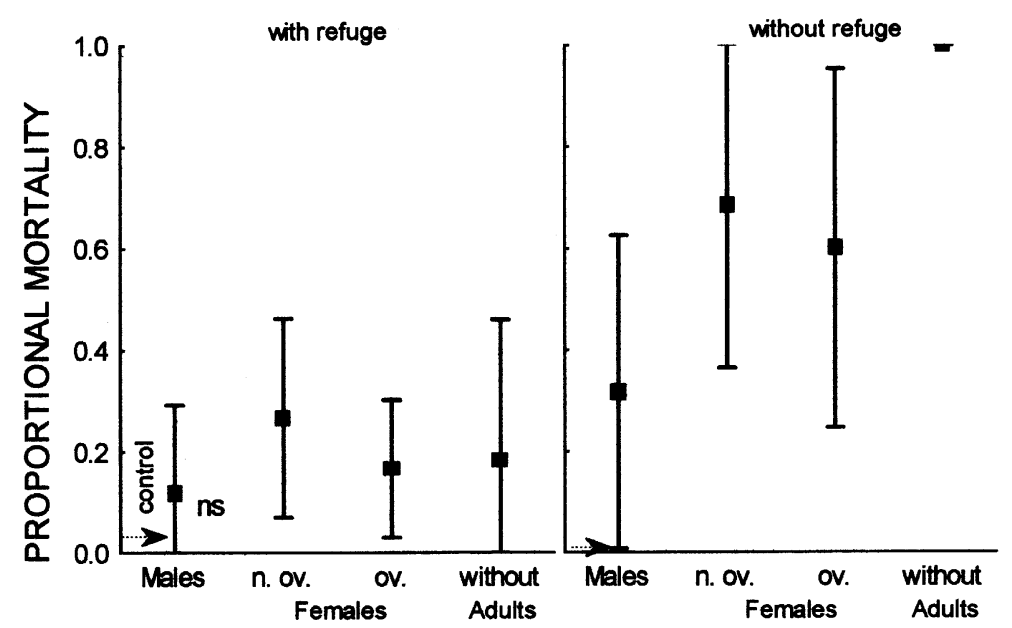

Fig. 5. Proportional mortality (mean \pm standard deviation) of $C$. granulata settlers with juveniles alone or juvenile plus adult male or non-ovigerous (n. ov.) females or ovigerous (ov.) females as predators, with or without refuge. For more explanations see caption of Fig. 2. 
Adults preyed on conspecific juveniles. Juvenile mortality was maximum in the presence of non-ovigerous females (30\% with, and $60 \%$ without refuge) and minimum with ovigerous females ( $20 \%$ and $40 \%$, respectively). Some juveniles autotomized one or more limbs in the presence of an adult, autotomies were most frequent $(30 \%)$ when juveniles shared the flask with non-ovigerous females.

\subsection{Sex-related morphometric differences in adult chelae}

The CW of males and females of both species used for study sex-related differences in chela size did not differ between sexes ( $C$. granulata $t=0.125, p=0.9$ and $C$.
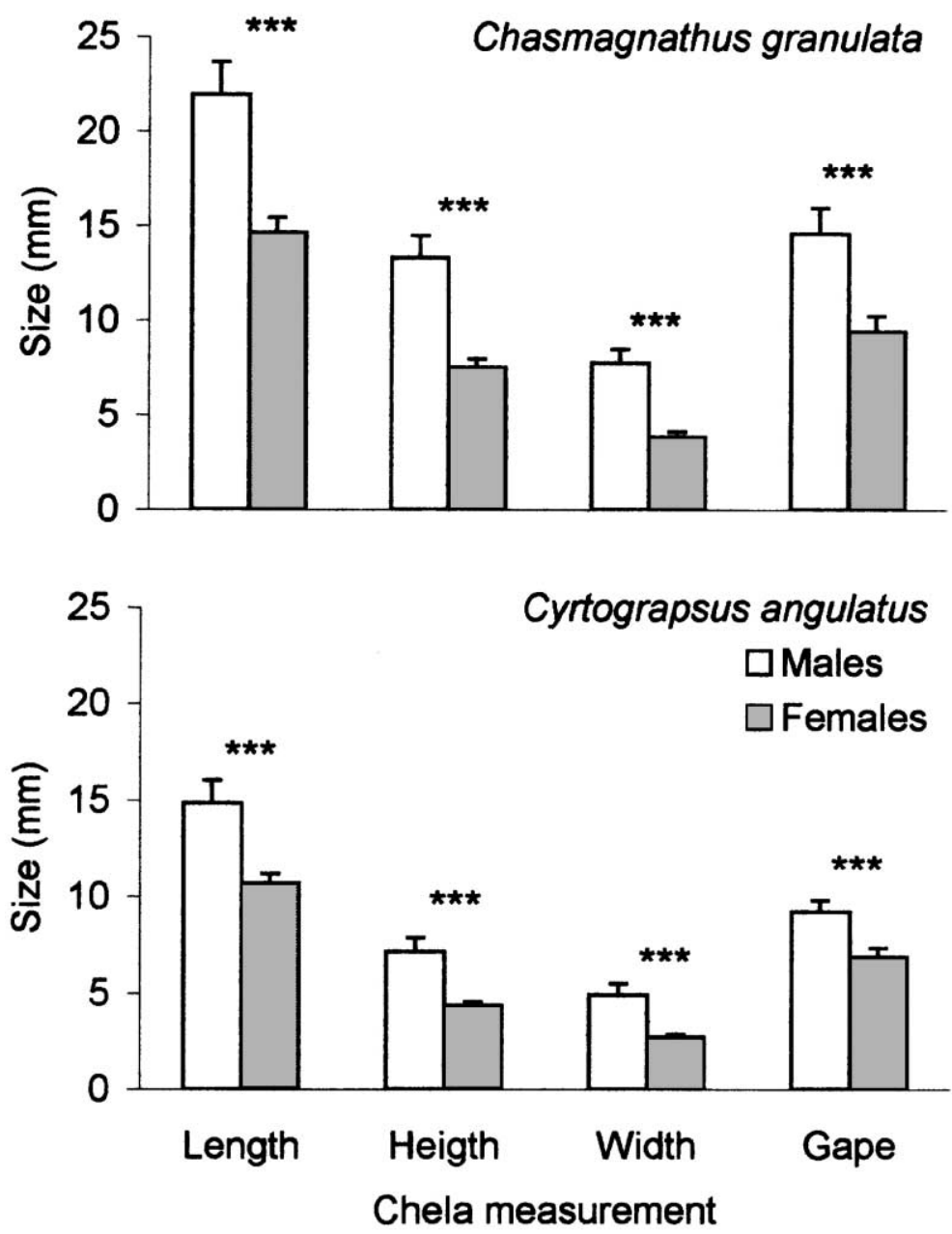

Fig. 6. Chelae length, width, height and gape (mean \pm standard deviation), in male and female adults of $C$. granulata and $C$. angulatus. ${ }^{* *} p<0.001, t$-test. 
angulatus $t=0.69, p=0.49)$ nor from the $\mathrm{CW}$ of adults used as predators in the experiments ( $C$. granulata $t=1.74, p=0.084$ and $C$. angulatus $t=1.5, p=0.137$ ). In both species, the chelae were longer in males than in females, but the sexual dimorphism is more marked in $C$. granulata than in $C$. angulatus, regardless of the dimension considered (Fig. 6).

\section{Discussion}

In laboratory experiments, juveniles and adults of both $C$. angulatus and $C$. granulata preyed on settlers of either species. The degree of predation depends primarily on the presence of refuges for prey, but also on the size and feeding condition of the predators, and on the presence or absence of alternative food. Moreover, there are interactions between predators of different sizes.

In short periods of time cannibalism among settlers caused only low mortality in both species, as observed also in other crab species (Kurihara and Okamoto, 1987; Lovrich and Sainte-Marie, 1997; Moksnes et al., 1997, 1998). This is probably due to uniform size within a cohort. The few observed cases of intracohort cannibalism may be a consequence of increased vulnerability of individuals that molted during the experiment. The number of settlers that molted during the experimental period ( 2 days) should be low because their intermolt period is longer (from 5 to 7 days in the laboratory; Luppi, 1999). Consequently, the incidence of intracohort cannibalism may be underestimated. Juveniles and adults that have ecdisys in laboratory, are cannibalized by others (Luppi, personal observation). Otherwise, not always the ecdisys increase the vulnerability to cannibalism (e. g. C. opilio; Dutil et al., 1997).

In crab and other decapod life histories, refuges are considered important for the survival of postlarvae, settlers or juveniles. Hence, they are a stabilizing factor in predator-prey interactions (Kurihara and Okamoto, 1987; Kurihara et al., 1988; Hudon and Lamarche, 1989; Navarrete and Castilla, 1990; Wilson et al., 1990; Heck and Hambrook, 1991; Olmi and Lipcius, 1991; Smith and Herrnkind, 1992; Fernández et al., 1993b). The presence of artificial refuges reduced predation and cannibalism by juveniles and adults of $C$. angulatus and $C$. granulata on settlers of both species. Dittel et al. (1995) discussed the theoretical concept of "absolute refuges", where prey are invulnerable, but they showed that in the field refuges gave a partial protection against predators. The protecting effect of refuges varied according to size and nutritional status of the predator: refuges allow settlers to escape more effectively from adults than from juveniles. On the other hand, starved juvenile $C$. angulatus caused a high conspecific settler mortality even in the presence of a refuge. Consequently, refuges may be highly effective (absolute) against adult predators while they may be less effective ("partial") against juvenile predators.

In Mar Chiquita, there are various refuges for the settlers of each species. Polychaete ( F. enigmaticus) "reefs" are the main refuge for $C$. angulatus settlers. Although several predators such as conspecific juveniles, adult $C$. altimanus and gobiid fishes inhabit these "reefs", settler survival may be higher in these structures than in the surrounding 
mudflats, where conspecific adults, fishes and birds live and feed. The surrounding mudflats offer little structural heterogeneity: beds of bivalve shells T. plebeius, cobbles and stones that covered a small portion of benthic habitat in the lagoon (Spivak et al., 1994; Gutierrez and Iribarne, 1998). This ontogenetic habitat shift in C. angulatus, where settlers and juveniles live in refuges, but adults live on open mud flats, corresponds with the "ontogenetic niche" concept (Werner and Gilliam, 1984). It can be considered as an adaptive response to predators (Williams et al., 1990; Richards, 1992). This hypothesis is consistent with evidence from laboratory experiments: $C$. angulatus megalopae prefer pieces of reef over mud for settlement, and settlers actively avoid conspecific adults (Luppi, 1999). Similar pattern of cannibalism-mediated habitat shift have been described for $C$. sapidus; crabs between 5 and $15 \mathrm{~mm}$ have an ontogenetic shift in habitat use from seagrass to unvegetated mud and sand (Moksnes et al., 1997; Pile et al., 1996).

C. granulata megalopae settle in or near the adult burrows, where various juvenile size-classes may coexist (Spivak et al., 1994). The burrows protect the settlers against fishes and birds, while the adults that live inside the burrows protect the settlers against predators including conspecific juveniles. Other terrestrial and semiterrestrial crabs have similar refuge behaviors (Kurihara et al., 1988; Wolcott, 1988; Cabrera Peña et al., 1994). Adult males diminished the otherwise strong juvenile cannibalism on settlers; however, ovigerous females had a weaker protective effect, and non-ovigerous females had no significant effect. These observations suggest that the adults preyed on juveniles and thus depressed their predatory activity. Adults preyed on juveniles both in the field and in the laboratory (Luppi, unpublished). Non-ovigerous females caused the highest mortality of juveniles and settlers, indicating a relationship between the reproductive status and foraging activity. The adult non-ovigerous females have preyed significantly on juveniles, but any beneficial effect for settlers of reduced juvenile predation may have been offset by adult predation of settlers. Similarly non-ovigerous females of $C$. polyodon and $C$. magister forage more than ovigerous females, and $C$. polyodon non-ovigerous females are more cannibalistic than ovigerous females (Cerdá and Wolff, 1993; Schultz et al., 1996). During 30-min observations, juvenile C. granulata attacked settlers when they were alone, but not in the presence of an adult crab (Luppi, unpublished results). Additional evidence suggests that burrows are the preferred recruitment habitat for this species; they act as "megalopae traps" under the hydrodynamic conditions in Mar Chiquita (Iribarne et al., 1997), and megalopae metamorphosed earlier in the presence than in the absence of a chemical stimulus from adult conspecifics (Gebauer et al., 1998).

Juveniles always caused higher settler mortality than adults. This difference probably can be explained by predator size difference, as smaller crabs had an easier access to parts of the refuge. On the other hand, adult chelae are large compared to prey size, which probably affects settler catchability. The chelae gape determines the maximum prey size in crabs (Elner and Hughes, 1978; Hughes and Elner, 1979; ap Rheinallt and Hughes, 1985; ap Rheinallt, 1986; Behrens Yamada and Boulding, 1998). However, large chela may be useless for catching small motile prey. In C. opilio, the minimum size of cannibalized juveniles may depend on the predator's ability to perceive the prey (optic, tactic, or otherwise signals), seize the prey, and/or on the predator's chela gape 
(Lovrich and Sainte-Marie, 1997). Settlers were frequently observed on adult carapaces, both in the field and the laboratory, where they remained unaccessible (Luppi, personal observation).

The difference between adult males and females in degree of cannibalistic behavior was greater in $C$. granulata than in $C$. angulatus. Although in both species the chelae of females were smaller than those of males, sexual dimorphism was greater in $C$. granulata (e.g. chela length differed by $50 \%$ in $C$. granulata, but by only $38 \%$ in $C$. angulatus). Relatively smaller chelae may allow females to extract the settlers even from refuges. In $H$. penicillatus, females eat smaller conspecifics than males; the difference in chelae gape is $50 \%$ in favor of male (Kurihara and Okamoto, 1987).

Predator hunger increased the consumption of settlers by larger crabs. This effect was statistically significant for adult $C$. angulatus. Hunger may initiate or increase predatory or cannibalistic behavior, especially at high densities (Fox, 1975; Polis, 1981; Wolcott, 1988). The refuges of both species have abundant detritus and microfauna but at higher juvenile and/or settler densities the food may become limiting. Experimental prey densities ( 6 individuals $/ 300 \mathrm{~cm}^{3}$ of refuge) corresponded to a moderate density in the field (Luppi, 1999); the presence of alternative food diminished predation, when refuges were available. At higher juvenile densities, alternative food may become scarce so that settlers will become more attractive as prey. Moreover settlers and juveniles eat the same food, so that intraspecific competition increases and a larger body size becomes increasingly advantageous as density grows (Botsford and Wickham, 1978), resulting in a competitive exclusion of settlers. Alternative food did not decrease cannibalism in $C$. maenas (Moksnes et al., 1998; Moksnes, 1999), but mussel flesh was used instead of a high concentration of small and highly motile Artemia nauplii. C. magister preference for alternative prey versus conspecifics varied depending on the prey offered and crab size: preference for shrimp and crabs (cannibalism) declined and consumption of clam and polychaetes increased as the crabs reached larger size (Visser, 1997).

C. granulata are also herbivores, although parts of conspecific crabs have been observed in the stomachs (Olivier et al., 1972b; D'Incao et al., 1990; Iribarne et al., 1997). Predation and cannibalism supplies additional nitrogen, vitamins and other essential substances to herbivore grapsid species, mainly when the quality and quantity of available plant food is low (Wolcott and O'Connor, 1992; Anger, 1995; Kennish, 1996). Some microhabitats and food sources are accessible only to settlers, due to their small size. In Mar Chiquita, $C$. angulatus settlers may reach spaces and food between polychaete tubes that are inaccessible to juveniles and adults. This "hidden" food becomes indirectly available to larger crabs through cannibalism (Wolcott and Wolcott, 1984). Juveniles prey on settlers and, in turn, are eaten by adults when they leave the reefs (Gavio and Iribarne, 1994). In such a way, a cannibalistic trophic net may allow adults to indirectly obtain food from the reefs.

It should be expected that the rate of cannibalism increases at the maximum densities found in refuges (40-50 individual/300 $\mathrm{cm}^{3}$; Luppi, 1999), as it happened in $C$. sapidus (Moksnes et al., 1997), C. opilio (Dutil et al., 1997) and C. maenas (Moksnes, 1999). At the beginning of summer in the natural habitat, when the first cohort of the year's settlers arrives in the lagoon, both settlers and juvenile densities are almost null (Luppi, 1999). The first megalopae have the highest chance of survival and molting in 
an environment depleted of cannibals. The first settlers grow quickly and become juveniles that prey upon the following cohorts of megalopae, and in consequence, new settlers will have a lesser chance of surviving. The larger $C$. magister of the first cohort cannibalized megalopae and instar I of subsequent cohorts in the refuge habitat (Fernández et al., 1993a), and the same pattern of saturation of nursery area and posterior cannibalism over new settlers was proposed for C. opilio (Lovrich et al., 1995). No settlers were observed migrating to other habitats (Spivak et al., 1994) and if this happens, they would probably be eaten by other predators.

C. granulata and C. angulatus showed a marked predatory and intercohort-cannibal activity in the laboratory, as other crab species (Fox, 1975; Polis, 1981; Reise, 1985; Kurihara and Okamoto, 1987; Hines et al., 1990; Fernández et al., 1993a; Moksnes et al., 1997). The results suggest that this activity may be very intense during the recruitment periods of both species and have an important role in the regulation of successive cohorts that arrive to refuges during 1 year.

\section{Acknowledgements}

We thank C. Bas and R. Zenuto for their field and laboratory assistance and J. Valero, G. Lovrich and M. Fernández for commenting on an earlier version of the manuscript. The manuscript was substantially improved by reviews by A.J. Underwood, and an anonymous reviewer. This investigation was part of a bilateral cooperation programme (MAR-8) between the Universidad Nacional de Mar del Plata (UNMDP), Argentina, and the Biologische Anstalt Helgoland, Germany. It was funded by Consejo Nacional de Investigaciones Científicas y Técnicas de la República Argentina (CONICET) and UNMdP grants to E.S. (PIP 838/98 and 15/E082) and fellowships to T. L., the Secretaría de Ciencia y Tecnología (Buenos Aires) and, on behalf of the German Federal Ministry of Education, Science and Technology (Bonn), by the International Bureau of the Alfred Wegner Institut fur Polar-und Meersforschung (Bremerhaven, Germany) and the Forschungszentrum Julich (Julich, Germany). This study represents a portion of a Doctoral Thesis of T.L. [AU]

\section{References}

Anger, K., 1995. Developmental biology of Armases miersii (Grapsidae), a crab breeding in supratidal rock pools. II. Food limitation in the nursery habitat and larval cannibalism. Mar. Ecol. Prog. Ser. 117, 83-89.

Anger, K., Ismael, D., 1997. Growth and elemental composition (C, N, H) in larvae and early juveniles of a South American salt marsh crab, Chasmagnathus granulata (Decapoda: Grapsidae). Mangroves Salt Marshes 1, 219-227.

Anger, K., Bas, C., Spivak, E., Ismael, D., Luppi, T., 1994. Hatching rhythms and dispersion of decapod crustacean larvae in a brackish coastal lagoon in Argentina. Helgol. Meeresunters. 48, 445-466.

ap Rheinallt, T., 1986. Size selection by the crab Liocarcinus puber feeding on mussels Mytilus edulis and on shore crabs Carcinus maenas: the importance of mechanical factors. Mar. Ecol. Prog. Ser. 29, 45-53. 
ap Rheinallt, T., Hughes, R.N., 1985. Handling methods used by the velvet swimming crab Liocarcinus puber when feeding on molluscs and shore crabs. Mar. Ecol. Prog. Ser. 25, 63-70.

Behrens Yamada, S., Boulding, E.G., 1998. Claw morphology, prey size selection and foraging efficiency in generalist and specialist shell-breaking crabs. J. Exp. Mar. Biol. Ecol. 220, 191-211.

Bertness, M.D., Gaines, S.D., Stephens, E.G., Yund, O.Y., 1992. Components of recruitment in populations of the acorn barnacle, Semibalanus balanoides (Linnaeus). J. Exp. Mar. Biol. Ecol. 156, 199-215.

Boschi, E., 1964. Los crustáceos decápodos brachyura del litoral bonaerense (R. Argentina). Bol. Inst. Biol. Mar. Mar del Plata 6, 1-99.

Botsford, L.W., Hobbs, R.C., 1995. Recent advances in the understanding of cyclic behavior of Dungeness crab (Cancer magister) population. ICES Mar. Sci. Symp. 199, 157-166.

Botsford, L.W., Wickham, D.E., 1978. Behavior of age-specific density-dependent models and the northern California Dungeness crab (Cancer magister) fishery. J. Fish. Res. Board Can. 35, 833-843.

Cabrera Peña, J., Vives Jiménez, F., Solano López, Y., 1994. Tamaños y proporción sexual de Ucides occidentalis (Crustacea: Gecarcinidae) en un manglar de Costa Rica. UNICIENCIA 11, 97-99.

Cerdá, G., Wolff, M., 1993. Feeding ecology of the crab Cancer polyodon in La Herradura Bay, northern Chile: II. Food spectrum and prey consumption. Mar. Ecol. Prog. Ser. 100, 119-125.

Connell, J.H., 1985. The consequences of variation in initial settlement vs. post-settlement mortality in rocky intertidal communities. J. Exp. Mar. Biol. Ecol. 93, 11-45.

D’Incao, F., Da Silva, K.G., Ruffino, M.L., Da Costa Braga, A., 1990. Habito alimentar do caranguejo Chasmagnathus granulata Dana, 1851 na barra do Rio Grande, RS (Decapoda, Grapsidae). Atlantica 12, $85-93$.

Dittel, A.I., Hines, A.H., Ruiz, G.M., Ruffin, K.K., 1995. Effects of shallow water refuge on behavior and density-dependent mortality of juvenile blue crabs in Chesapeake Bay. Bull. Mar. Sci. 57, 902-916.

Dutil, J.D., Munro, J., Péloquin, M., 1997. Laboratory study of the influence of prey size on vulnerability to cannibalism in snow crab (Chionoecetes opilio O. Fabricius, 1780). J. Exp. Mar. Biol. Ecol. 212, 81-94.

Eggleston, D.B., Armstrong, D.A., 1995. Pre- and post-settlement determinants of estuarine Dungeness crab recruitment. Ecol. Monogr. 65, 193-216.

Elner, R.W., Hughes, R.N., 1978. Energy maximization in the diet of the shore crab, Carcinus maenas. J. Anim. Ecol. 47, 103-116.

Fernández, M., 1999. Cannibalism in Dungeness crab Cancer magister: effect of predator-prey size ratio, density, and habitat type. Mar. Ecol. Prog. Ser. 182, 221-230.

Fernández, M., Armstrong, D., Iribarne, O., 1993a. First cohort of young-of-the-year Dungeness crab, Cancer magister, reduces abundances of subsequent cohorts in intertidal shell habitat. Can. J. Fish. Aquat. Sci. 50, $2100-2105$.

Fernández, M., Iribarne, O., Armstrong, D., 1993b. Habitat selection by young-of-the-year Dungeness crab Cancer magister and predation risk in intertidal habitats. Mar. Ecol. Prog. Ser. 92, 171-177.

Fox, L.R., 1975. Cannibalism in natural population. Annu. Rev. Ecol. Syst. 6, 87-106.

Gaines, S.D., Roughgarden, J., 1985. Larval settlement rate: a leading determinant of structure in an ecological community of the marine intertidal zone. Proc. Nat. Acad. Sci. U. S. A. 82, 3701-3711.

Gavio, A., Iribarne, O., 1994. Distribución espacial, selección de hábitat y tasa de mortalidad de Cyrtograpsus angulatus en la albúfera Mar Chiquita: la importancia del canibalismo. Abstract, II Taller sobre cangrejos y cangrejales Mar del Plata.

Gebauer, P., Walter, I., Anger, K., 1998. Effect of substratum and conspecific adults on the metamorphosis of Chasmagnathus granulata (Dana) (Decapoda: Grapsidae) megalopae. J. Exp. Mar. Biol. Ecol. 223, $185-198$.

Gosselin, L.A., Qian, P., 1997. Juvenile mortality in benthic marine invertebrates. Mar. Ecol. Prog. Ser. 146, $265-282$.

Gutierrez, J.L., Iribarne, O., 1998. The occurrence of juvenile of the grapsid crab Chasmagnathus granulata in siphon holes of the stout razor clam Tagelus plebeius. J. Shell. Res. 17, 925-929.

Gutierrez, J.L., Iribarne, O., 1999. Role of Holocene beds of the stout razor clam Tagelus plebeius in structuring present benthic communities. Mar. Ecol. Prog. Ser. 185, 213-228.

Heck, K.L., Wilson, K.A., 1987. Predation rates on decapod crustaceans in latitudinally separated seagrass communities: a study of spatial and temporal variation using tethering techniques. J. Exp. Mar. Biol. Ecol. $107,87-100$. 
Heck, K.L., Hambrook, J.A., 1991. Intraspecific interactions and risk of predation for Dyspanopeus sayi (Decapoda: Xanthidae) living on Polychaete (Filograna implexa Serpulidae) colonies. Mar. Ecol. 12, 243-250.

Hines, A.H., Ruiz, G.M., 1995. Temporal variation in juvenile blue crab mortality: nearshore shallows and cannibalism in Chesapeake Bay. Bull. Mar. Sci. 57, 884-901.

Hines, A.H., Lipcius, R.N., Haddon, A.M., 1987. Population dynamics and habitat partitioning by size, sex and molt stage of blue crab Callinectes sapidus in a subestuary of central Chesapeake Bay. Mar. Ecol. Prog. Ser. 36, 55-64.

Hines, A.H., Haddon, A.M., Wiechert, L.A., 1990. Guild structure and foraging impact of blue crabs and epibenthic fish in a subestuary of Chesapeake Bay. Mar. Ecol. Prog. Ser. 67, 105-126.

Hudon, C., Lamarche, G., 1989. Niche segregation between American lobster Homarus americanus and rock crab Cancer irroratus. Mar. Ecol. Prog. Ser. 52, 155-168.

Hughes, R.N., Elner, R.W., 1979. Tactics of a predator, Carcinus maenas, and morphological responses of the prey, Nucella lapillus. J. Anim. Ecol. 48, 65-78.

Hurlbert, S.J., 1984. Pseudoreplication and the design of ecological field experiments. Ecol. Monogr. 54, $187-211$.

Iribarne, O., Bortolus, A., Botto, F., 1997. Between-habitat differences in burrow characteristics and trophic modes in the southwestern Atlantic burrowing crab Chasmagnathus granulata. Mar. Ecol. Prog. Ser. 155, $137-145$.

Kennish, R., 1996. Diet composition influences the fitness of the herbivorous crab Grapsus albolineatus. Oecologia 105, 22-29.

Keough, M.J., Downes, B.J., 1982. Recruitment of marine invertebrates: the role of active larval choices and early mortality. Oecologia 54, 348-352.

Kneib, R.T., Lee, S.Y., Kneib, J.P., 1999. Adult-juvenile interactions in the crabs Sesarma (Perisesarma) bidens and S. (Holometopus) dehaani (Decapoda: Grapsidae) from intertidal mangrove habitats in Hong Kong. J. Exp. Mar. Biol. Ecol. 234, 255-273.

Kurihara, R.A., Okamoto, K., 1987. Cannibalism in a grapsid crab Hemigrapsus penicillatus. Mar. Ecol. Prog. Ser. 41, 123-127.

Kurihara, Y., Sekimoto, K., Miyata, M., 1988. Wandering behaviour of the mud-crab Helice tridens related to evasion of cannibalism. Mar. Ecol. Prog. Ser. 49, 41-50.

Lovrich, G.A., Sainte-Marie, B., 1997. Cannibalism in the snow crab, Chionoecetes opilio (O. Fabricius) (Brachyura: Majidae), and its potential importance to recruitment. J. Exp. Mar. Biol. Ecol. 211, $225-245$.

Lovrich, G.A., Sainte-Marie, B., Smith, B.D., 1995. Depth distribution and seasonal movements of Chionoecetes opilio (Brachyura: Majidae) in Baie Sainte-Marguerite, Gulf of Saint Lawrence. Can. J. Zool. 73, 1712-1726.

Luckenbach, M.W., 1984. Settlement and early post-settlement survival in recruitment of Mulinia lateralis (Bivalvia). Mar. Ecol. Prog. Ser. 17, 245-250.

Luppi, T.A., 1999. La coexistencia de dos especies de cangrejo en el ecosistema del cangrejal: estudio comparativo del asentamiento y el reclutamiento (The coexistence of two crab species in the "cangrejal" ecosystem: comparative study of settlement and recruitment) $\mathrm{PhD}$ Thesis, Mar del Plata University, p. 101.

Marcovecchio, J., de Marco, S., Pozzobon, V., Gavio, A., Asteasuain, R., Rusansky, C., Ferrer, L., Andrade, S., Freije, H., 1997. The role of estuaries as buffer zones to the littoral marine environment: the case of Mar Chiquita coastal lagoon, in Argentina. Abstract. VII Congresso Latino-americano sobre Ciencias do Mar., pp. 128-130.

Martos, P., Reta, R., 1997. Aspectos hidrográficos de la región estuarial de la laguna de Mar Chiquita, Pcia. de Buenos Aires. Abstract. II Congreso argentino de Limnologia, 18-24.

Moksnes, P.O., 1999. Recruitment regulation in shore crab. Doctoral Thesis. Göteburg University. Sweden.

Moksnes, P., Lipcius, R., Pihl, L., van Montfrans, J., 1997. Cannibal-prey dynamics in young juveniles and postlarvae of the blue crab. J. Exp. Mar. Biol. Ecol. 215, 157-187.

Moksnes, P.O., Pihl, L., van Montfrans, J., 1998. Predation on postlarvae and juvenile of the shore crab Carcinus maenas: importance of shelter, size and cannibalism. Mar. Ecol. Prog. Ser. 166, 211-225.

Navarrete, S., Castilla, J., 1990. Resource partitioning between intertidal predatory crabs: interference and refuge utilization. J. Exp. Mar. Biol. Ecol. 143, 101-129. 
Obenat, S., Pezzani, S., 1989. Ecological studies of Ficopomatus (Mercierella) enigmaticus (Annelidae: Polychaeta) in Mar Chiquita coastal lagoon (Buenos Aires, Argentina). Conservation and development: the sustaintable use of wetland resources. Third International Wetlands Conference, Editions du Musèum d'Historie Naturelle, Paris, pp. 165-166.

Okamoto, K., Kurihara, Y., 1989. Feeding habitat and food selection of the grapsid crab Hemigrapsus penicillatus Jpn. J. Ecol. 39, 195-202.

Olivier, S., Escofet, A., Penchaszadeh, P., Orensanz, J., 1972a. Estudios ecológicos de la región estuarial de Mar Chiquita (Bs. As., Argentina). I. Las comunidades bentónicas. An. Soc. Cient. Argent. 193, 237-262.

Olivier, S., Escofet, A., Penchaszadeh, P., Orensanz, J., 1972b. Estudios ecológicos de la región estuarial de Mar Chiquita (Bs. As., Argentina): II. Relaciones tróficas interespecíficas. An. Soc. Cient. Argent. 194, 89-104.

Olmi, E.J., Lipcius, R.N., 1991. Predation on postlarvae of the blue crab Callinectes sapidus Rathbun by sand shrimp Crangon septemspinosa Say and grass shrimp Palaemonetes pugio Holthius. J. Exp. Mar. Biol. Ecol. 151, 169-183.

Pile, A.J., Lipcius, R.N., van Montfrans, J., Orth, R.J., 1996. Density dependent settler:recruitment:juvenile relationship in blue crab: mechanism and effects of a tropical storm. Ecol. Monogr. 66, 277-300.

Polis, G.A., 1981. The evolution and dynamics of intraspecific predation. Annu. Rev. Ecol. Syst. 12, 225-251.

Polis, G.A., 1988. Explotation and the evolution of interference, cannibalism and intraguild predation in age/size structured populations. In: Ebenmen, B., Persson, L. (Eds.), Size structured populations. Springer, Berlin Heidelberg, pp. 183-202.

Reise, K., 1985. Tidal flat ecology. Ecological studies, vol. 54 Springer-Verlag, Berlin, 76 pp.

Reta, R., Martos, P., Piccolo, M.C., Perillo, G.M., Ferrante, A., 1997. Características de la marea en la laguna costera Mar Chiquita, Argentina. Abstract. VII Congresso Latino-americano sobre Ciencias do Mar., pp. $330-332$.

Richards, A.R., 1992. Habitat selection and predator avoidance: ontogenetic shifts in habitat use by the Jonah crab Cancer borealis (Stimpson). J. Exp. Mar. Biol. Ecol. 156, 187-197.

Rivera Prisco, M.A., 1998. Alimentacion de juveniles de lenguado (Pleuronectiformes) en la laguna costera Mar Chiquita (Pcia. de Buenos Aires). Licenciature Thesis, Mar del Plata University, p. 57.

Ruiz, G.M., Hines, A.H., Posey, M.H., 1993. Shallow water as a refuge habitat for fish and crustaceans in non-vegetated estuaries: an example from Chesapeake Bay. Mar. Ecol. Prog. Ser. 99, 1-16.

Schultz, D.A., Shirley, T.C., O’Clair, C.E., Taggart, S.J., 1996. Activity and feeding of ovigerous dungeness crabs in Glacier Bay, Alaska. High Latitude Crabs: Biology, Management, and Economics. Univ. Alaska Sea Grant Rpt. 96-02, pp. 411-424.

Smith, L.D., 1995. Effect of limb autotomy and tethering on juvenile blue crab survival from cannibalism. Mar. Ecol. Prog. Ser. 116, 65-74.

Smith, K.N., Herrnkind, W.F., 1992. Predation on early juvenile spiny lobsters Panulirus argus (Latreille): influence of size and shelter. J. Exp. Mar. Biol. Ecol. 157, 3-18.

Spivak, E.D., Anger, K., Bas, C., Luppi, T.A., Ismael, D., 1994. Distribution and habitat preferences of two grapsid crab species in Mar Chiquita lagoon (Province of Buenos Aires Argentina). Helgol. Meeresunters. $48,59-78$.

Spivak, E.D., 1999. Effects of reduced salinity on juvenile growth of two-occurring congeneric grapsid crabs. Mar. Biol. 134, 249-257.

Thorson, G., 1966. Some factors influencing the recruitment and establishment of marine benthic communities. Neth. J. Sea Res. 3, 267-293.

Underwood, A.J., 1997. Experiments in ecology. Cambridge Univ. Press, Cambridge, p. 504.

Visser, E.P., 1997. Competition, cannibalism, and prey limitation: factors compromising the effectiveness of shell habitat mitigation for early benthic phase Cancer magister in Gray harbor, WA. PhD thesis, University of Washington, Seattle, 1997.

Werner, E.E., Gilliam, J.F., 1984. The ontogenetic niche and species interactions in size-structured populations. Annu. Rev. Ecol. Syst. 15, 393-425.

Williams, A.H., Coen, L.D., Stoelting, M.S., 1990. Seasonal abundance, distribution, and habitat selection of juvenile Callinectes sapidus (Rathbun) in the northern Gulf of Mexico. J. Exp. Mar. Biol. Ecol. 137, 165-183. 
Wilson, K.A., Able, K.W., Heck, K.L., 1990. Predation rates on juvenile blue crabs in estuarine nursery habitats: evidence for the importance of macroalgae (Ulva lactuca). Mar. Ecol. Prog. Ser. 58, 243-251.

Wolcott, T.G., 1988. Ecology. In: Burggren, W.W., McMahon, B.R. (Eds.), Biology of the Land Crabs. Cambridge Univ. Press, Cambridge, pp. 55-96.

Wolcott, D.L., O'Connor, N.J., 1992. Herbivory in crabs: adaptations and ecological considerations. Am. Zool. 32, 370-381.

Wolcott, D.L., Wolcott, T.G., 1984. Food quality and cannibalism in the red land crab, Gecarcinus lateralis. Physiol. Zool. 57, 318-324. 